\title{
НАПРЯМИ ТРАНСФОРМАЦІЇ РЕПОРТАЖУ В ОНЛАЙНОВІЙ ЖУРНАЛІСТИЦІ
}

\author{
Мирослава Чабаненко \\ Запорізький національний університет, \\ вул. Жуковського, 66-а, 69600, Запоріжжя, Україна \\ e-mail: MV letters@ukr.net \\ https://orcid.org/0000-0002-4583-8910
}

У статті всесторонньо розглянуто трансформаційні зрушення, що відбуваються 3 жанром репортажу в Інтернеті на прикладі низки матеріалів інтернет-ЗМІ. Підтверджуючи адаптацію цього жанру до середовища Інтернету і появу його новітніх різновидів, автор вказує на зміни у часових межах одного репортажу та підходах до забезпечення ефекту присутності.

Ключові слова: традиційний репортаж, інтернет-3МІ, інтернет-журналістика, онлайн-репортаж, репортаж із соцмереж.

Постановка проблеми. Останніми роками є і залишається постійно актуальною тема змін у класичній системі журналістських жанрів, викликаних наступом інтернет-технологій. Зокрема, чималу увагу дослідники приділяють репортажу одному з найосновніших і найстаріших жанрів, який «у мережі заново народився», зберігши при цьому свою «родову подієву і миттєву сутність» [1, с. 129]. В інформаційному просторі Павутини його традиційні різновиди закономірно набувають суто інтернетних рис. Також доводиться спостерігати появу новітніх модифікацій жанру, обумовлену застосуванням сучасних підходів до роботи над матеріалами репортажного спрямування. Очевидним є те, що самої лише констатації цих процесів і фрагментарних спроб їх пояснення сьогодні недостатньо. Назріла потреба в ї комплексному вивченні та формулюванні чітких, а головне - повних узагальнень для кращого розуміння специфіки впливу нових медіа на журналістику.

Аналіз досліджень із проблематики роботи. Ще у 2009 р. М. Василенко вказував на те, що класична форма репортажу в сучасному медіа-просторі «явно не спрацьовує» [2]. Причина «насамперед в інертності творчого мислення, що спровокована загальною масифікацією свідомості сучасного суспільства 3 відповідною атрибутикою цього явища: пануванням аудіовізуальних 3MI, швидкою зміною інформаційних потоків у режимі роботи в інтернеті, деформацією класичної системи гуманітарної освіти тощо» [2]. Нині репортаж сприймається «лише як жанр, що повідомляє про певну подію», «як різновид інформаційної кореспонденції» [2], при

(C) Чабаненко М., 2019 
тому, що в репортажі класичної форми, завдяки особливому літературному викладу, дійсність зображується мальовничо, яскраво, детально, небайдуже.

За відомим визначенням І. Михайлина, жанр - це нерозривна змістовно-формальна єдність, у якій більш значущим складником виступає зміст. Саме на репортаж звикли дивитись як на жанр, що «передбачає оперативну і яскраву розповідь про подію, ситуацію, явище» від імені очевидця або учасника, подану впереміш із суб'єктивними враженнями останнього [3, с. 380].

На думку Л. Городенко, основні ознаки жанрів у їх класичному розумінні мають зберігатися незалежно від того, в яких медіа вони представлені - нових чи традиційних. А ось один із висновків, яких вона дійшла, дослідивши контент низки онлайнових 3МI: «говорити про досконалість жанрів у мережі нема сенсу», адже «кожен, хто знає букви і вміє скласти слова у примітивне речення, може виступити в інтернеті виробником інформації» [4, с. 49].

Безумовно, банальна непрофесійність деяких працівників онлайнових 3МI здатна відбиватися на якості репортажів. Проте ясно, що набагато важливішу роль у змінах відіграє широкий спектр технічних можливостей, якими володіють інтернет-журналісти, та корінна властивість Мережі - порівняно вільний обіг інформації, а також пов'язаний із нею доступ аудиторії до мас-медійної діяльності.

На погляд С. Вировцевої, трансформаційні зрушення, стосовно всіх жанрів в Інтернеті, найбільше видно: 1) у способах і прийомах відображення реальності; 2) у принципах показу позиції автора матеріалу; 3) у ступені участі аудиторії у створенні журналістського твору [5, с. 209]. Цю думку підтверджують зауваження всіх дослідників, які тією чи іншою мірою торкались питання функціонування репортажу в онлайновій журналістиці.

Для того, щоб матеріал, перенесений із друкованого видання, набув органічного вигляду на сайті, у ньому обов'язково мають міститися гіперпокликання. «У середньому в репортажі обсягом до п'яти тисяч знаків в інтернет-виданні нараховується до п’яти-семи посилань», - зазначає О. Хіренко у статті, присвяченій дослідженню комунікативного потенціалу інформаційних матеріалів друкованих 3МI [6, с. 40]. Прикметно, що застосування гіперпокликань посилює комунікативний аспект, допомагає аудиторії більш грунтовно ознайомлюватись із інформацією, але водночас відволікає від гармонійного сприйняття тексту [6, с. 40].

Репортажі в інтернеті на прикладі матеріалів сайту «ЛітАкцент» (litakcent.com) досліджував В. Тарасюк, відзначивши наявність багатьох різновидів цього жанру: інформаційні, подієві, тематичні, проблемні репортажі, репортажі-звіти, репортажі-роздуми, репортажі-зарисовки, зрідка - репортажі-інтерв’ю. За його спостереженням, Інтернет дає «майже необмежені можливості для використання світлин», тому невипадково, на його думку, багато саме фоторепортажів [7, с. 251]

Аналізуючи фото в нових медіа, Я. Табінський вказує на те, що фоторепортажі «часто вирізняються надмірною серійністю»: це властиво передовсім регіональним інтернет-3МI, «де редакторам доцільніше опублікувати більше фото з окремими деталями події, ніж шукати кілька різнопланових, справді вартісних фотографій високої якості та формулювати до них якісні підписи» [8, с. 330].

Побутує термін «мультимедійний репортаж», у якому відображений той факт, що інтернет-репортажі можуть нести інформацію в кількох доступних форматах од- 
ночасно [9, с. 136]. Газетно-журнальна формула текст плюс фото розширюється до текст плюс фото, відео, аудіо і т. д.

Крім гіпертекстуальності та мультимедійності, на зміни в жанрі репортажу в Павутині впливає інтерактивність. Інтернет-журналіст відчуває себе частиною аудиторії, з якою активно спілкується, тому «якщо у блозі буде опублікований репортаж з місця подій, то автор буде не просто створювати ефект присутності, а й давати оцінку подіям, які відбулися (або відбуваються)», - підкреслюють Є. Цимбаленко, К. Соколова [10, с. 81].

Крім того, репортаж в Інтернеті може бути зведений «до безперервного постингу коротких інформаційних повідомлень 3 місця подій у соціальних мережах» $[10$, c. 81$]$.

Такий термін як «блоговий репортаж», за О. Сомовою, означає «видову форму репортажного жанру», у структурі якого «вирізняється особливий підвид - mвim-peпортаж» [11, с. 20]. Останній є проявом, перш за все, громадянської журналістики, хоча серед авторів блогів зустрічаються професійні журналісти, які готують свої публікації в рамках безпосередньої роботи на редакцію того чи іншого ЗМІ.

«Твіт-репортажі» містять авторське ставлення до події, ефект присутності в них часто забезпечується завдяки вбудовуванню в матеріал інтерв’ю. Їх самобутні риси продиктовані технічною платформою. У «твіт-репортажі» «посилюється оперативність і персоніфікованість» інформації, це робить його дуже привабливим для аудиторії. Його феномен викликаний «сполученням прагнення до об’єктивності 3 гіперсуб'єктивністю та емоційністю» [11, с. 21].

Про виникнення такої форми представлення контенту згадує також О. Градюшко. За його спостереженням, прийоми користування Twitter у роботі журналіста дуже різноманітні: крім одержання інформації та стеження за конкурентами, це інструмент здійснення Twitter-трансляцій із публічних акцій, спортивних змагань, місць надзвичайних пригод; причому повідомлення в Twitter можна ілюструвати фото-, відео- або аудіофайлами [12, с. 123].

Інтернет-видання, присвячені спортивній журналістиці (Tribuna.com, Pressball. by та ін.), практикують онлайн-репортажі або, як їх іще називають, текстові онлайн-трансляції, коли журналіст збирає матеріал поступово, поки триває спортивний захід, подаючи невеликі порції текстових повідомлень із фото, з позначенням точного часу [13, с. 115-116].

Онлайн-репортаж став популярним для висвітлення прес-конференцій, судових засідань, різних масових акцій. «Інтернет трансформував жанр і додав йому нову форму, - підсумовує О. Градюшко. - Зараз репортаж може поєднувати в собі не лише текст, але й численні фото, відео, аудіо, інфографіку тощо» [12, с. 139]. На його думку, можливість швидкої публікації та оновлення в режимі реального часу наповнила цей жанр новим змістом, даючи змогу досягати ефекту присутності за рахунок ведення репортажу паралельно розгортанню події [12, с. 139].

Аналізуючи контент онлайн-3МІ «Страна» strana.ua, Д. Дьячкова та О. Куцевська помітили, що цей сайт подає репортажі з подій, побудовані за принципом зворотної хронології, з фото та відео, коментарями безпосередніх учасників, авторів та експертів у реальному часі, посиланнями на минулі повідомлення, прогнозами аналітиків тощо [14, с. 148-149]. 
Як бачимо, різні дослідники, намагаючись окреслити явище трансформації репортажу в Інтернеті, зупиняються лише на тих чи інших окремих аспектах, а в узагальненнях враховують не всі деталі.

Мета і завдання. Така розпорошеність думок спонукає до їх об'єднання, перевірки та систематизації. Узявши це до уваги, в нашому дослідженні ми спробували з'ясувати, як проявляє себе репортаж в Інтернеті, підпорядковуючись глобальним тенденціям, на сайтах інформаційних агентств, друкованої преси, аналогового телебачення, ефірних радіостанцій і суто інтернетних видань. Для цього було проаналізовано контент 30 інтернет-ЗМI; вибірка формувалась на основі пошуку за словом «репортаж».

Результати і висновки. Найперше, що стало зрозуміло, навіть у інформаційному середовищі нових медіа, жанр репортажу цілком здатний залишатися у своїх класичних вимірах. Це можна побачити насамперед на сайтах газет, де журналісти звикли працювати у традиційному ключі та виставляють в Інтернеті матеріали підкреслено газетного вигляду. Показовим прикладом щодо цього є репортаж із Центру бойової підготовки Національної гвардії України, опублікований на сайті газети «Сільські вісті» silskivisti.kiev.иa 17.06 .14 р. Його текст проілюстрований кількома невеликими фото, підготовлений із майстерним застосуванням методу репортажного опису дійсності, містить включені інтерв'ю, образну мову, авторське ставлення, роздуми («Ці люди готові, якщо потрібно, вмерти, але від них віє потужною енергією життя. Я на них дивився з більшою повагою, ніж на нардепів, міністрів чи популярних артистів, бо за своїм суспільним статусом вони значно вищі. Відчувається, що кожен зазнав мук вибору, багато переосмислив і має сформовану філософію подвигу, в основі якої - патріотизм і самопожертва» [15]). Але в ньому немає навіть гіперпосилань. Подібні матеріали є більш характерними для обласних періодичних друкованих видань (приклад - репортаж «Настільний теніс, натхнення і мрії»на сайті газети «Зоря Полтавщини» zorya.poltava.ua за 05.02.2019).

Такий підхід зрозумілий i, мабуть, цілком виправданий (підкреслює професійність у класичному розумінні на противагу «моді»), якщо за сайтом стоїть редакція газети, та ще й із багаторічною історією. Однак навіть газетярі схильні брати на озброєння сучасні інтернет-технології. Флагманами у цій справі виступають газети «День», «Дзеркало тижня», «Сьогодні», які, зокрема, публікують фоторепортажі 3 використанням зручних слайдерів і фотогалерей (приклади: «Осінь продовжує радувати киян теплою погодою та різноманіттям кольорів», «День» day.kyiv.ua, 10.10.18 p.; «Святкування Різдва на Софійській площі: фоторепортаж», «Дзеркало тижня» dt.ua, 08.01.19 р.; «На месу Папи Римського в ОАЕ прийшли 150 тис. людей: з'явилися вражаючі фото», «Сьогодні» segodnya.ua, 05.02.19 р.).

Такі матеріали ще й містять чимало гіперпосилань, супроводжуються формами для коментарів, можуть супроводжуватись прив'язками до соцмереж (кнопки «подобається», «поділитися» тощо). Цікаво, що випадків публікації репортажів, адаптованих у такий спосіб до інформаційного простору Інтернету, помітно більше, ніж неадаптованих і зі збереженими класичними підходами (другі необхідно довго шукати).

Репортажі, опубліковані в Інтернеті, часто відрізняються значними розмірами фотоілюстрацій, великою кількістю знімків (приклад-«“Водій автобуса. 140 кг ваги. Яка ДРГ?!”, - репортаж з Енергодару - батьківщини Євгена Панова», «Цензор.НЕТ» 
censor.net.ua, 11.08 .16 р.). Нерідко застосовується технологія, що дозволяє користувачам збільшувати знімки наведенням курсору або кліком («У музеї презентували туристичні маршрути Пологівщини», «Пологівські вісті» polvisti.com, 26.06.2018 р.).

Деякі інтернет-видання подають репортажі у вигляді лонгрідів, що означає особливу верстку, зокрема світлини в таких матеріалах займають весь (або майже весь) екран. Приклади - «Ровесник США, або Як виживає найстаріший кінний завод країни», «Українська правда» pravda.com.ua, 25.10 .18 р.; «Школа для космічного хлопчика», «The Ukrainians» theukrainians.org, 28.01.19 p.

Традиційні радійний і телевізійний репортажі, будучи представленими в Інтернеті відповідно аудіо- та відеоподкастами, теж здебільшого набувають інтернетних рис внаслідок впливу гіпертекстуальності й інтерактивності. Внаслідок медіа-конвергенції вони можуть виступати як аудіо- чи відеоілюстрації до матеріалу, в центрі якого перебуває текст, частково гублячи характер самостійного медіа-повідомлення (приклад - «Шпигунський репортаж: журналістка ТСН під прикриттям улаштувалася санітаркою в лікарню» за 21.06.15 р. на сайті ТСН tsn.ua).

Поруч із цим трапляються зовсім нові різновиди репортажів, які за своєю структурою, стилем i, тим більше, за технічним виконанням значно відійшли від класичних. Це онлайн-репортаж і репортаж із соимереж.

Для онлайн-репортажів журналісти беруть інформаційні приводи, що стосуються: однієї тривалої події, яка відбувається протягом дня (приклад - «Об’єднавчий собор церков в Україні: онлайн», «Кореспондент» korrespondent.net, 15.12.18 р.); кількаденного розгортання дрібних подій навколо однієї надважливої (приклад - «Повернення Саакашвілі в Україну» «Гордон» gordonua.com, 12.09.17 р.). Часто такі матеріали кілька разів оновлюються, інформація може нарощуватись як знизу (рідше), так і згори (зворотній хронологічний порядок).

Суцільні текстові онлайн-репортажі 3 однієї довгої події інтернет-видання «Гордон» називає онлайн-трансляціями (приклад - «В Інституті серця пройшли вибори гендиректора, ним залишився Тодуров», 18.12.18р.), хоча цей термін частіше вживають на позначення інтернет-публікацій, які містять відео наживо. На сайті «Кореспондент» korrespondent.net подібні матеріали можуть називатися хронікою nодій (приклад - «Справа Савченко», 13.04.18 р.).

Для репортажів із соцмереж інформаційними приводами стають сплески обговорень тієї чи іншої події, що викликала широкий резонанс у суспільстві. Приклади: «День селфі в музеї», НB Style style.nv.ua, 17.01 .18 р.; «Святковий забіг. У Києві, Одесі та Дніпрі влаштували пробіжки у вишиванках» «Новое время» nv.ua, 21.11.2018 р. Подібні матеріали нагадують огляди, а іноді - замітки із серії «реакція соцмереж», але називаються репортажами. Напевно тому, що формально вони близькі до онлайн-репортажів, у яких теж прийнято застосовувати скріншоти.

Останні два різновиди репортажів становлять окремий дослідницький інтерес через те, що їх існування ламає стереотипне уявлення про найголовнішу жанрову ознаку репортажу - ефект присутності, точніше - про його створення. Якщо у матеріалах, просто адаптованих до Інтернету, цей ефект іще передбачає фізичну присутність журналіста на події як обов’язкову умову його застосування, то в репортажах iз соцмереж, і деякою мірою в онлайн-репортажах, журналіст «присутній» (не фізично, а ментально) в епіцентрі певного інформаційного збурення тим, що моніторить протягом певного часу висвітлення тієї чи іншої новини в інтернет-3МІ та соцмере- 
жах. Такий зсув може бути цілковитим або частковим, якщо журналіст побував на одному, дотичному до тривалої події, яка підлягає висвітленню, заході, а про решту дізнався із чужих інтернет-повідомлень, зокрема $з$ дописів відвідувачів соцмереж.

Одночасно з перерахованими трансформаціями жанру мають місце зміни у вимогах до роботи журналістів, адже підготовка репортажів нових різновидів передбачає володіння дуже конкретним набором професійних знань і навичок. Зокрема це стосується вміння грамотно опрацьовувати дані з соцмереж (що викликає сьогодні багато критики).

Таким чином, ясно, що хоча класичний різновид репортажу мало представлений в Інтернеті та не зовсім органічно сприймається в контексті нових медіа, неправильно говорити про занепад жанру репортажу загалом. Радше спостерігаємо його бурхливий розвиток, якому інтернет-технології значною мірою сприяють, відкриваючи для нього нові виміри, зокрема вперше даючи журналістам змогу: 1) висвітлювати кількаденну подію в межах одного матеріалу з поступовим оновленням публікації; 2) заміняти фізичну присутність репортера на події уважним моніторингом інформаційних потоків.

Перспективи подалыших досліджень. Подальші перспективи досліджень могли б полягати, по-перше, у точному з'ясуванні правомірності вживання назви «репортаж» стосовно матеріалів, які журналісти готували без виїзду на події (репортажі з соцмереж і частково онлайн-репортажі), оскільки, можливо, йдеться про підміну понять, а не про нові різновиди жанру. А по-друге - у з'ясуванні деталей та більш чіткому формулюванні вимог до підготовки репортажів для інтернет-ЗМI (зокрема щодо оптимального обсягу матеріалу, кількості джерел, сполучення медіаформатів), аби молоде покоління журналістів мало змогу переймати цей досвід ще у процесі навчання у вишах.

\section{REFERENCES}

1. Журналистика и конвергенция: почему и как традиционные СМИ превращаются в мультимедийные / под ред. А. Г. Качкаевой. М., 2010. 200 с.

2. Василенко М. К. Репортаж. Подолання жанрової кризи. Електронна бібліотека Інституту журналістики. URL : http://journlib.univ.kiev.ua/index. php?act $=$ article $\&$ article $=2367$

3. Михайлин I. Л. Основи журналістики : підручник. 5-те вид. перероб. та доп. Київ : Центр учбової літератури, 2011. 496 с.

4. Городенко Л. М. Тенденції розвитку інформаційних жанрів в українському Інтернеті / Science and Education a New Dimension. Humanities and Social Sciences, 2016. IV (12). Issue: 76. C. 46-49.

5. Выровцева Е. В. Трансформация традиционных публицистических жанров в современных массмедиа. Вестник Челябинского государственного университета : Научный журнал. Филология. Искусствоведение. 2015. № 5 (360). Вып. 94. С. 207-213.

6. Хіренко О. О. Інформаційні жанри друкованих ЗМК як складова комунікаційного процесу. Держава та регіони : Науково-виробничий журнал. Серія : Соціальні комунікації. Запоріжжя : КПУ, 2015. № 2 (22). С. 37-42.

7. Тарасюк В. Специфіка репортажу в українській інтернет-журналістиці (за матеріалами сайту «ЛітАкцент»). Науковий вісник Ужгородського університету. Серія: 
Філологія. Соціальні комунікації. Ужгород : Видавництво УжНУ «Говерла», 2011. Випуск 26. С. 245-251.

8. Табінський Я. Фотографія у системі нових медій. Вісник Львівського університету. Серія журналістика. ЛНУ ім. Івана Франка, 2013. Випуск 37. С. 226-333.

9. Универсальная журналистика : учеб. для вузов / под ред. Л. П. Шестёркиной. М. : Издательство «Аспект Пресс», 2016. 480 с.

10. Цимбаленко С., Соколова К. Трансформація журналістських жанрів (на прикладі інтернет-медіа). Інформаційне суспільство. 2013. Вип. 13. С. 80-83.

11. Сомова Е. Твитт-репортаж на сайтах радиостанций информационного формата. Новое в массовой коммуникации. 2013. № 03-04 (114-115). Воронеж : Факультет журналистики Воронежского государственного университета. С. 20-23.

12. Градюшко А. Современная веб-журналистика Беларуси. Минск : БГУ, 2013. 180 с.

13. Градюшко А. А. Жанрово-стилистические особенности новостной веб-журналистики. Веснік Мазырскага дзяржаўнага педагагічнага ўніверсітэта імя I. П. Шамякіна. 2014. № 3(44). С. 114-118.

14. Дьячкова Д. В., Куцевська О. С. Сучасні жанри інтернет-журналістики. Мас-медіа України на зламі епох: реалії та перспективи розвитку. Матеріали Всеукраїнської науково-практичної інтернет-конференції (20-21 березня 2018 року, м. Старобільськ). Старобільськ, ДЗ «ЛНУ імені Тараса Шевченка». 2018 С. 144-153.

15. Карпенко О. На війні своїх не кидають. Репортаж із Центру бойової підготовки Національної гвардії України. URL: http://www.silskivisti.kiev.ua/19112/index. php?n=22741 


\title{
DIRECTIONS OF REPORTAGE TRANSFORMATION IN ONLINE JOURNALISM
}

\author{
Myroslava Chabanenko \\ Zaporizhzhia National University \\ Zhukovskogo St., 66-a, 69600, Zaporizhzhia, Ukraine \\ e-mail: MV letters@ukr.net \\ https://orcid.org/0000-0002-4583-8910
}

The article deals with the transformational changes that occur with the reportage genre on the Internet. First of all, the author proves the formulated scientific problem - the scientific works carried out in this direction have a lack of integrity and systemicity. In view of the need to review the opinions of other researchers, the author analyzes examples of reportage messages published on the Internet, referring to the sites of traditional paper editions, radio, television, news agencies, and purely online editions. As a result, three groups of processes were outlined. The first is the functioning of the traditional types of reportage on the Internet in the virtually unchanged form, that is, in the form typical for the classical manifestation of this genre. Among them, traditional photographic reports and reports with features of artistic journalism, which contain a figurative language, an author's attitude, and which use the method of a reportage description of reality in the classical way. The second group is the adaptation of the reportage genre to the Internet due to the acquisition of its specific features. In this case, the main factors of the shifts are hypertext, multimedia, interactivity, civil journalism. The third group is associated with the emergence of entirely new varieties of reportage genre, first of all - online reportage and reportage from social networks. It is noted that Internet technologies bring not only additional means of ensuring the effect of presence. The author points to changes in the time limits of reportage - now one publication can cover an event that lasted two or three days. In addition, there has been a shift in approaches to ensuring the effect of presence - the physical presence of a journalist on the event is not already obligatory. Because of this, there is an uncertainty about the correct usage of the term "reportage" in relation to some reports of online media.

Key words: traditional reportage, internet media, internet journalism, online reportage, reportage from social networks. 